\title{
Correction to: A Morally Permissible Moral Mistake? Reinterpreting a Thought Experiment as Proof of Concept
}

\author{
Nathan Emmerich (D) B Bert Gordijn
}

Published online: 18 March 2019

(C) The Author(s) 2019

Correction to: Bioethical Inquiry (2018) 15:269-278

https://doi.org/10.1007/s11673-018-9845-x

There was a spelling error in the second author's last name in the original publication. The name is correct in this erratum.

Open Access This article is distributed under the terms of the Creative Commons Attribution 4.0 International License (http:// creativecommons.org/licenses/by/4.0/), which permits unrestricted use, distribution, and reproduction in any medium, provided you give appropriate credit to the original author(s) and the source, provide a link to the Creative Commons license, and indicate if changes were made.

Publisher's Note Springer Nature remains neutral with regard to jurisdictional claims in published maps and institutional affiliations.

The online version of the original article can be found at https://doi.org/10.1007/s11673-018-9845-x

N. Emmerich · B. Gordijn

Institute of Ethics, Dublin City University, Dublin, Ireland

N. Emmerich $(\bowtie)$

School of History, Anthropology, Politics and Philosophy, Queen's University Belfast, Belfast, UK

e-mail: n.emmerich@qub.ac.uk 